\title{
Poesia e Psicanálise: Um possível diálogo entre Manoel de BarRos, FReUd e LACAN
}

Tiago Antonio Sampaio ${ }^{1}$

\section{Resumo}

O presente artigo buscou apresentar características da poesia de Manoel de Barros em um possível dialogo com a psicanálise de Freud e Lacan. Os desdobramentos para este enlace se deram através da perspectiva psicanalítica do texto freudiano de Escritores Criativos e Devaneios, e o conceito de objeto a de Lacan, ambos articulados a lançar um olhar sob a singularidade na poesia de Manoel de Barros, em poemas que retratam o sujeito em sua simplicidade, incompletude, e mais, propõe o homem como funcional mesmo no lugar de des-idealizado.

PALAVRAS-CHAVE: Poesia. Psicanálise. Manoel de Barros. Freud. Lacan. Objeto a.

${ }^{1}$ Psicanalista. Poeta. Músico. Psicólogo graduado em Psicologia pela Universidade Anhanguera de Santo André. Rua Antonio Pereira Machado, 279, PQ São Rafael, 08320-130, São Paulo, SP. 11 94741-9485. CRP 06/137501. tiago.a.sampaio@hotmail.com. 


\section{INTRODUÇÃO}

Manoel de Barros elege ao longo de sua obra uma poesia que direciona um olhar ao desimportante, as coisas (aparentemente) desimportantes, e mais, faz com que sejam tratadas e retratadas como uma espécie da mais singela homenagem para com aquilo que se assemelha a identificação do poeta, ao tempo em que trata das coisas e situações mais mnêmicas e in-úteis do ser.

Através de uma sutileza peculiar Barros destina seu ponto de vista acerca do que o cerca, colidindo a notável complexidade da beleza com a profunda simplicidade das coisas, na medida em que resgata um mundo de simples absurdos que ha muito foi deixado pelo homem ao preço de um ideal (de sociedade) como testemunhamos nos dias atuais, onde o homem não possui escolha a não ser, se tornar o ideal de si mesmo (e do outro). O outro de Manoel de barros é o avesso, as miudezas, as coisas rasteiras, o lixo e o que fora jogado fora. Olhando assim de viés, pode ate parecer que o poeta prefira a decadência, mas vale lembrar que esse poeta compreende que o conceito das coisas uma vez globalizadas, não permite espaço para que possa oferecer o que há de singular nelas a partir do sujeito. Dito isso, pode se dizer que já não se trate de uma escolha sob a decadência, mas sim, de aceitar a capacidade de viver na incompletude, onde não se faz necessário a perfeição.

Desta forma ao observar na poesia de Manoel de Barros as características acima citadas, e de modo a acomodar a singularidade de sua escrita em uma possível interlocução com a psicanálise de Freud e Lacan, o presente artigo propõe um caminhar de modo a observar o ato criativo do poeta por uma perspectiva freudiana, ao tempo em que aponta na linguagem monoelesca um estilo singular que assemelha se ao sujeito da psicanálise. Para isso o conceito de objeto a de Lacan se fez pertinente para a realização deste exercício, de modo a apresentá-lo pela via da poesia, e esta, sendo manifesta através da angustia, seu meio possível.

Deste modo, apresento o caráter inicial de uma jornada como psicanalista de quem vos escreve... Um enunciado que agora enuncia. Quando o que se busca é, articular a psicanálise através da poesia é por assim dizer que, há poesia na psicanálise. Desta forma, assumo a responsabilidade com o que escrevo mesmo sabendo que são as palavras responsáveis por mim, por elas sou representado, e não quem as representa... E isso basta. Basta como a minha verdade, o meu não saber. 


\section{Manoel de Barros, Vida em Obra.}

Manoel Wenceslau de Leite Barros ou simplesmente Manoel de Barros, foi um poeta pantaneiro que nasceu em Cuiabá (MT) em 19 de dezembro de 1916. Viveu parte de sua infância no Pantanal, onde pode sentir a terra em seus pés, e a possibilidade de conviver entre os bichos, coisas e objetos que chamavam a atenção do futuro poeta conforme aponta trecho da sua biografia no site da Fundação Manoel de Barros. No período escolar Barros fora para Campo Grande e posteriormente para um colégio interno no Rio de Janeiro, assim tendo contato pela primeira vez com os livros do Padre Antônio Vieira, com o qual se identificou e viu-se diante daquilo que viria a ser o seu mais ímpeto e verdadeiro ofício, ser poeta. E desta forma foi tomado pelo gosto da escrita e consequentemente da poesia.

Tinha 13 anos, no internato dos maristas. Era sozinho, não tinha parente,
ficava lá no recreio, jogando futebol. Tinha um padre meu amigo que jogava
futebol, e jogava de batina. Era talvez o mais desprezado do colégio, porque
vivia sujo. Mas era também o mais inteligente mais culto. (...) Ele então me
deu Padre Antônio Vieira. Fiquei deslumbrado com Vieira. E descobri que a
importância da literatura é a harmonia da frase. Descobri a frase. (BARROS,
2009, O ESTADO).

E é no sentido primário da palavra descobrir, ou seja, de tirar o véu que até então encobria, por assim dizer uma habilidade de Manoel, que a escrita torna-se para o poeta como uma forma de encontrar um afeto, uma saída para lidar com o próprio deslocamento.

Manoel de Barros elege ao longo de sua obra uma poesia que direciona um olhar ao desimportante, as coisas (aparentemente) desimportantes, e mais, faz com que sejam tratadas e retratadas como uma espécie da mais singela homenagem para com aquilo que se assemelha a identificação do poeta, ao tempo em que trata das coisas e situações mais mnêmicas e in-úteis do ser.

Barros proporciona em sua poesia uma funcionalidade para o que não é idealizado, faz de um lugar onde não se pode planear, para um lugar onde tudo pode ser.... Um devir. Como pode ser observado no trecho a seguir, "Não é por me gavar, mas eu não tenho esplendor. Sou referente pra ferrugem, mais do que referente pra fulgor. Não serei mais um pobre-diabo que sofre de nobrezas, só as coisas rasteiras me celestam" (BARROS, [1993] 2015, p. 97).

Manoel de Barros através de uma sutileza peculiar destina seu ponto de vista acerca do que o cerca, colidindo a notável complexidade da beleza com a profunda simplicidade das coisas (que, por alguma razão, foram esquecidas e/ou desprovidas

28 Psicanálise \& Barroco em revista | v.16, n. 01 | julho de 2018 
de valor), na medida em que resgata um mundo de simples absurdos que ha muito foi deixado pelo homem ao preço de um ideal de sociedade como testemunhamos nos dias atuais, onde o homem não possui escolha a não ser, se tornar o ideal de si mesmo e do outro e conforme demostra, através do poema Autorretrato falado:

Me criei no Pantanal de Corumbá, entre bichos do chão, pessoas humildes, aves, árvores e rios. Aprecio viver em lugares decadentes por gosto de estar entre pedras e lagartos, fazer o desprezível ser prezado é coisa que me apraz. (BARROS, [1993] 2015, p. 89).

E desta forma, ao direcionar o olhar não apenas para uma infância pantaneira, Barros também reivindica uma nova função, um novo olhar e uma possibilidade para as coisas e objetos a sua volta, fazendo do habitual, o extraordinário, como pode se observar, por exemplo, em Bernardo personagem presente em alguns dos poemas do autor, como em "Ele é quase árvore" (1993), Bernardo guarda em seu velho baú alguns itens e instrumentos de trabalho da invencionaria de Barros, como "um abridor de amanhecer", "um prego que farfalha", "um encolhedor de rios", e "um esticador de horizontes". (BARROS, 1993). Manoel de Barros está para a possibilidade tanto quanto a falta está para o desejo, ou seja, faz-se o possível onde quer que possa devir.

Houaiss (1992) refere-se à poesia de Manoel de Barros como uma invenção poética que possui personalidade própria, rara até entre os grandes poetas, e complementa que o tempo em que somos inspirados pelo divino, somos com a mesma destreza, capazes de praticar as maiores torpezas com os nossos semelhantes. Dito isso, torna-se encantador ver irradiar de maneira tão pertinente e harmoniosa na poesia de Manoel de Barros a certeza de que entre o homem e o caramujo há um nexo necessário que deveria nos tornar seres mais solidários com a vida. Barros convence com a doçura e adequação de suas palavras, que pode ser possível, um caminhar confortável através da vida, uma prece de harmonia na vida universal, um momento de bondade em que há algo de irônico, de lírico, de doce, de solitário e esperançoso. "A poesia de Manoel é um maravilhoso filtro contra a ignorância, a exploração, a estupidez, a cobiça, a burrice, não se propondo, ao mesmo tempo ensinar nada a ninguém, senão que a vida”. (HOUAISS, 1992 p. 6).

Barros quebra com a fragilidade do que é indubitável, não se deixa cercar pelas leis gramaticais e permite-se a inventar, a incorporar a imagem ao verbo, como um atrevimento de criança. Como figura a seguir "Em poesia que é voz de poeta, que é voz de fazer nascimento, o verbo tem que pegar delírio, (...) como quando a criança 
diz: Eu escuto a cor do passarinho" (BARROS, 1994, p.17). É através da desconstrução acerca da habitualidade, que o poeta produz uma palavra imaginativa e assim mutua-mente, como evidencia nesta sequência poética, ao dizer que "imagens são palavras que nos faltaram - poesia é ocupação da palavra pela imagem - poesia é a ocupação da imagem pelo ser" (BARROS, 1956 p. 20).

Desta forma o poeta também descontrói a própria identidade, pois busca o valor ao dessaber, busca em si e no mundo uma existência que não esteja fadada ao cumprimento do consuetudinário e que carrega consigo o ouro das desutilidades, aproxima-se assim com simplicidade a complexidade dos próprios abismos, e compreende a importância das pequenas coisas desimportantes:

A identidade do poeta é forjada no dessaber. A poesia está na altura da criança, "nas coisinhas do chão/ É um olhar para baixo que nasci tendo./ É um olhar para o ser menor, /para o insignificante que eu me criei tendo.33 $\mathrm{A}$ infância em Barros é vivida na maturidade como recurso de resgate e possibilidade de brincar/ser/ desaprender no presente e como tal constitui um olhar especial, cheio porque vazio. Aparentemente uma desvalorização ou deboche, sugere um truque pela consciência do seu oposto - o que pressupõe a utilização consciente do dessaber como estratégia. Por isso o adulto precisa alcançar a ignorância das coisas, resgatar o momento anterior à conceituação, enfim, desaprender, porque ser bocó, ser simples é paradoxalmente a condição para ficar com a complexidade dos abismos. (RIBAS, 2011 pag. 147).

Se até o presente parágrafo a compreensão da poesia de Barros indica um grau elevado de complexidade, é por assim dizer, que o poeta aborda em si a própria complexidade. O objetivo da poesia de Manoel de Barros não está na categoria do explicável, mas sim na função de desexplicar e porque não? De des-idealizar? Castello (2015) ressalta que a poesia barroneana ultrapassa a razão e se apega à infância, momento da vida que os sentidos estão ainda para serem estruturados. $O$ caráter infantil possui a liberdade de cultivar a visão indireta e enviesada sobre as coisas, um olhar volúvel e não reto. A razão ainda não pertence ao modo como contempla e enxerga o mundo, podendo assim trabalhar com inversões, descolamentos e deformações, como toda uma realidade que se inverte ao dizer que, "o córrego ficava a beira de um menino" (BARROS, 1998), ou "eu pendurei um bemte-vi no sol" (BARROS, 1993), Manoel de Barros desconstrói a si próprio através da palavra. Barros desta forma cria uma maneira de tentar liberta-se da censura do bom senso, não apenas do próprio poeta, mas do valor célebre e da verdade absoluta que os adultos, em geral, atribuem às palavras. "Um primeiro ponto da poesia barroneana 
que vale ser destacado é o criançamento da palavra, ao modo como figura à linguagem ao expor suas ignorãças poéticas”. (SILVA, 2009, p. 542).

Barros ao que parece é desobediente com a escrita e com a palavra, mais precisamente com o sentido da língua, porém, como mencionado anteriormente essa possível desobediência trata-se na verdade de uma desconstrução, e não a faz perder o sentido, mas sim encontrar outros sentidos possíveis, um olhar para aquilo que é e está, entretanto, foi negado ou deixado na categoria dos esquecidos. Esse olhar de tom aparentemente infantil, abusado e ao mesmo tempo reconciliador, é capaz de provocar e levar a uma possível reflexão acerca das coisas que estão ao redor, onde o homem se redescobre através desses novos sentidos. (GONÇALVES, 2012).

Ao observar o poeta fazendo com que a escrita apresente um caráter privilegiado, e por sua conduta singular, Barros propicia que uma linha possa ser traçada em direção com o trabalho da psicanálise, mais propriamente com o de Freud em "Escritores criativos e devaneios" (1908), quando aponta um elo entre a criança e o poeta através do ato criativo. Como uma forma de tornar a imaginação palpável num sentido de uma desconstrução não apenas estética, mas também da de um poeta que propõe uma travessia para além do que o sujeito tem como pragmático.

\section{A Psicanálise e o Ato Criativo}

Freud em seu texto "Escritores criativos e devaneios" ([1908] 2015) inicia com uma interessante e particular curiosidade em identificar no poeta/escritor meios que forneçam e/ou indiquem um ponto de acesso para o ato criativo, bem como de que maneira é permitido aos escritores que as palavras em seu domínio tornam-se capazes de provocar o mais relicário e profundo significado para aqueles que apreciam o seu feito. Dito isso, a curiosidade estende-se à medida que ao ser interrogado em qual fonte a água da poesia é tragada ou então de onde vem tal inspiração para o ato de sua criação artística, o poeta/escritor será de certa forma vago e não suficientemente claro, de maneira a indicar que não existe em si, ou em outra extensão, tal privilégio. De modo a assegurar que "no íntimo somos todos poetas, e só com o último homem morto morrerá o último poeta" (FREUD, [1908] 2015, p. 77), e se Freud em 1908 já indicaria essa imprecisão do poeta, Manoel de Barros, cem anos depois, em 2009, a ratificaria novamente ao dizer que "inspiração conheço só de nome" e ainda, "sempre que desejo contar alguma coisa não faço nada, mas sempre que não desejo contar nada, faço poesia" (BARROS, 1997, p.12).

Psicanálise \& Barroco em revista | v.16, n. 01 | julho de 2018 
Entretanto para tal pergunta, a imprecisão do poeta em sua resposta não se vincula ao resultado de um segredo a sete chaves, mas sim a uma questão que remete a sua criação por uma via tão natural quanto enigmática para o mesmo. "O artista mostra em sua obra o extrato de seu inconsciente, a sua verdade latente, ou ainda, uma representação indizível do desejo do inconsciente". (GUZZO, 2007). Doravante, utilizou-se a nomenclatura poeta para representar a categoria dos escritores neste presente exercício, bem como há de ser justo para com quem o trabalho apresentado utilizou-se do material, ou no caso, a poesia de Manoel de Barros.

Em caráter investigativo, bem como pertencente ao da psicanálise, Freud em Escritores criativos e devaneios ([1908] 2015) busca uma implicação com o fenômeno que o poeta produz, levantando assim uma possível e interessante hipótese ao observar na infância os primeiros traços de atividade imaginativa. Explanando que a criança ao brincar se comporta da mesma maneira que o poeta, pois é na medida do brincar que a criança, reajusta os elementos da realidade socialmente compartilhada, de modo que possa dar conta melhor dela segundo os seus recursos de maneira que sejam mais prazerosas, ora, da mesma forma que o poeta através de seu oficio.

Será que deveríamos procurar na infância, já os primeiros traços de atividade imaginativa? A ocupação favorita da criança é o brinquedo ou os jogos. Acaso não poderíamos dizer que ao brincar toda criança se comporta como um escritor criativo, ou melhor, reajusta elementos de seu mundo de uma nova forma que lhe agrade? (FREUD, [1908] 2015, p.82)

O pensamento freudiano aponta no artigo de 1908 algumas ressalvas. A primeira leva em conta que, ao contrário do que poderia supor, as crianças tomam á sério esse mundo na qual estão inseridas com suas fantasias e medos, uma vez que é reconhecido investimento de emoção para tal ação. E a segunda demostra que a antítese do brincar não é o que é sério, mas sim o que é real. De fato, mesmo com a emoção dispensada para com o seu mundo imaginativo, a criança igualmente ao poeta, é capaz de distinguir perfeitamente entre este mundo inventado e a realidade, capaz até de utilizar-se disso para ligar seus objetos e situações imaginativas às situações da própria realidade. Essa conexão é tudo o que diferencia o brincar infantil do fantasiar:

O escritor criativo faz o mesmo que a criança que brinca. Cria um mundo de fantasia que ele leva muito a sério, isto é, no qual investe uma grande quantidade de emoção, enquanto mantém uma separação nítida entre o mesmo e a realidade. (FREUD, [1908] 2015, p.86)

32 Psicanálise \& Barroco em revista | v.16, n. 01 | julho de 2018 
A necessidade de enfatizar entre o brincar e o fantasiar se dá pelo fato de que, como observa Freud ([1908] 2015), quando a fase da criança chega ao seu ciclo final e então dá lugar para a vida adulta, este adulto já não brinca mais (no dicionário de sinônimos, uma expressão de sentido aproximado a palavra brincar, é recrear-se, interessante pensar na relevância deste termo em sua sonoridade, e que talvez como adultos devêssemos nos recriar mais em nosso cotidiano). Não se permite estar em contato, ao menos a nível consciente, com a sua imaginação e infantilidade tão presente e dominante quanto na época com a qual isso é aceitável e permitido, ou seja, quando adulto o sujeito não se entrega aos seus desejos, ou melhor, a lidar com a sua falta de maneira tão honesta e franca quanto quando era uma criança, o que não quer dizer que não busque satisfação de alguma forma. Dito isso, "a criança em crescimento, quando para de brincar, só abdica do elo com objetos reais; em vez de brincar, ela agora fantasia. Constrói castelos no ar e cria o que chamamos de devaneios" (FREUD, [1908] 2015, p.92)

Essa é uma das notáveis similaridades que Freud ([1908] 2015) faz entre 0 poeta e a criança, de maneira a elucidar tal dificuldade do adulto em se haver com os seus desejos, uma vez que o adulto envergonha-se de algumas de suas fantasias, ora por serem consideradas infantis ou até mesmo proibidas, e como afirma Freud, "toda fantasia é a realização de um desejo" (FREUD [1908] 2015, pg. 94). O que torna o recriar algo de fácil consumação para a criança, seja diante da realização de um desejo ou diante da própria angústia, como pode concluir Freud ([1920] 2015) ao observar o neto Ernest recreando-se com o carretel de linha, fazendo com que o objeto desaparecesse e aparecesse na medida em que a criança o arremessava por entre a cortina e o puxava de volta para perto de si:

Para elaborar o afastamento da mãe, o pequenino transformava a ansiedade e separação vivida de forma passiva em algo ativo por meio de sua brincadeira. Simbolicamente o carretel representava a mãe, e ele tinha o "poder" de coloca-la longe ou perto dele, minimizando assim a sua angústia frente a separação por meio da capacidade simbólica. Esta criança não chora com a partida da mãe, ao contrário, transforma essa experiência em jogo. (CASTRO \& STURMER, 2009, p. 29)

As fantasias das pessoas adultas, como aponta Freud ([1908] 2015) são menos fáceis de observar do que o recrear-se das crianças. A criança brinca sozinha ou estabelece de certa forma um sistema psíquico fechado com outras crianças, com olhar direcionado a este jogo, e mesmo que não brinque na presença dos adultos, não 
Ihes oculta seu brinquedo, seu brincar, seu intento. $O$ adulto envergonha-se de suas fantasias, o encobre das outras pessoas. Afaga suas fantasias como seu bem mais precioso, e em geral optaria a confessar suas falhas do que confiar a outro suas fantasias, seus ensejos.

A busca para um possível esclarecimento acerca ato criativo do poeta em como se dá esse movimento por meio de uma estética encantadora, Freud ([1908] 2015) se debruça, e volta o olhar em uma possível comparação entre a criação do poeta ao do brincar infantil. Morais (2006) acredita que nessa comparação possa aludir a uma esfera significativa acerca dessa fase da vida, se tornando então, não apenas uma comparação dinâmica, mas também de um ponto de vista altamente valioso:

Se a nossa infância nos fascina, é talvez por ser ela em si o tempo de fascinação, de estarmos fascinados com a fascinação materna, idade dourada, tabula rasa das primeiras impressões, fadadas a reluzirem vida afora, claro brilho de uma época, fonte de todos os poderes de encantamento. Mesmo se um poeta estivesse encerrado numa prisão minúscula, tendo á sua frente apenas muros embolorados, ainda assim tiraria o seu material poético de recordações de sua infância. Ou dos desenhos do bolor esverdeado impregnando os muros, ou dos odores que impregnam o espaço. Tudo a ser escrito está dentro de nós, basta acha-lo. (MORAIS, 2006, p.22).

Notavelmente esta é observação pertinente capaz de acompanhar o raciocínio de Freud através do trajeto que percorre na exploração da criação artística, e mais, talvez respondendo a pergunta de Freud acerca do encanto que o poeta produz em quem aprecia a sua obra. Seja devido a certa cumplicidade que cria com o leitor que então toma aquela mensagem para si e a usufrui, e com ela se realiza para com seus próprios anseios. (MORAIS, 2006).

Em vias não apenas comparativas, mas de forma a complementar e elucidar de maneira significativa esta busca e olhar pela janela da psicanálise acerca do poeta e as possíveis articulações com ato de brincar infantil, conforme demostra Freud em Escritores criativos e devaneios ([1908] 2015), visto que sua utilidade se fez presente até o quanto foi interessante para este trabalho, não necessariamente encerrando a questão da criança e o brincar, mas a acrescentar, em suma, um poeta que nos demostra de forma única esta "comparação freudiana" entre a criança e o poeta, por isso acredita-se ser pertinente à escolha como representante da poesia, Manoel Barros. 
Eu tenho um ermo enorme dentro do olho, Por motivo de ermo não fui um menino peralta. Agora tenho saudade do que não fui. E com esta senectez atual me voltou a criances. Acho que o que eu faço agora é o que não pude fazer na infância. Faço outro tipo de peraltagem. Quando era criança eu deveria pular muro do vizinho para catar goiaba. Mas não havia vizinho. Em vez de peraltagem eu fazia solidão. Brincava de fingir que pedra era lagarto. Que lata era navio. Que sabugo de milho era boi. Eu era um serzinho mal resolvido e igual a um filhote de gafanhoto. Cresci brincando no chão, entre formigas. De uma infância livre e sem comparamentos. Eu tinha mais comunhão com as coisas do que comparação. Porque se a gente fala a partir de ser criança, a gente faz comunhão: de um orvalho e sua aranha, de uma tarde e suas garças, de um pássaro e sua árvore. Então eu trago das minhas raízes crianceiras a visão comungante e obliqua das coisas. Eu sei dizer sem pudor que o escuro me ilumina. É um paradoxo que ajuda a poesia e que eu falo sem pudor. Eu tenho essa visão obliqua vem de eu ter sido criança em algum lugar perdido onde havia transfusão da natureza e comunhão com ela. Era o menino e os bichinhos. Era o menino e o sol. O menino e o rio. Era o menino e as árvores. (BARROS, [1993] 2015, p. 15)

Como demostra Manoel de Barros ao tomar em sua poesia uma maneira de elucidar a infância como o núcleo de seu ato criativo, se aproxima muito do pensamento freudiano acerca desse movimento do poeta e da criança, não que esse fosse o objetivo para tal exercício, entretanto, Barros proporciona pela via poética o que Freud ([1908] 2015) propôs em seu trabalho ao buscar no poeta/escritor meios que indicassem o caminho por qual percorre o artista até a execução de sua arte. Certo de que Barros (2009) estivesse sendo honesto acerca de sua imprecisão no que compete à raiz da poesia, ao dizer sobre a inspiração e que a mesma a conhecia apenas por nome. É no cerne de seu trabalho que se pode compreender onde a inspiração emerge, e mais, aproxima a poesia e a psicanálise, ao menos por enquanto ao ponto em que a dinâmica criativa do artista "repete" um movimento infantil para dar vida ao seu trabalho.

No que comtempla Barros ([1993] 2015) através de seu poema Manoel por Manoel, o que aproxima o poeta do mundo com tamanha compaixão e sensibilidade se deve ao fato de buscar um retorno na infância e assim representar com a sua atualidade, de uma maneira que recolhe no passado um afeto para com o qual ainda carrega as marcas e se utiliza deles para uma possível conciliação com o presente e 
ainda lança um olhar para o futuro. Sobre esta relação entre passado, presente e futuro interligados pelo fio do desejo, "o poeta no presente busca em suas vivências passadas material para o seu escrito e o lança no futuro, a dizer o que não sabe e mais do que quis dizer, o poema sabe mais que quem o escreve" (MORAIS, 2006).

\section{A Angústia, a Poesia, o Objeto A.}

Na medida em que o enlace sobre uma possível interlocução entre a poesia de Manoel de Barros e a psicanálise se torna viável durante o percurso do presente artigo, sendo apresentada uma breve introdução acerca da vida e obra do poeta Manoel de Barros, e a partir de uma contemplação sobre o trabalho realizado por Freud em Escritores criativos e devaneios (1908), mediante a comparação do ato criativo do poeta ao brincar infantil da criança, sendo essa observação, apresentada apontada, aludida e posta em exercício apoiada aos estudos e pesquisas realizadas. Desta forma, chegamos ao ponto em que o artigo apresenta uma possível interlocução entre a poesia e a psicanálise. Acrescento então, uma interface para que este enlace seja capaz de ser fixado.

A abordar a angústia no Seminário, livro X, Lacan propicia a definição do status do objeto em sua teoria, não por menos, traz a angústia para a categoria dos afetos e ainda, a única maneira de falar sobre o objeto a seria através desta estrutura, ou seja, a angústia. "Se ele se inscreve no âmbito de um Seminário que intitulei de $\mathrm{A}$ angústia, é por ser essencialmente por esse meio que se pode falar dele, o que também quer dizer que a angústia é sua única tradução subjetiva". (LACAN [1962-1963] 2005, p. 113).

O objeto a apresenta uma dimensão que ultrapassa qualquer tentativa de retrata-lo em sua íntegra no presente trabalho. Dessa forma limitou-se a apontar o que Lacan propõe ao enunciar as possibilidades estruturais da manifestação do objeto a, como, objeto causa do desejo e a angustia sendo o afeto fundamental que acomete o sujeito em sua falta, e na impossibilidade de nomear este objeto. Lacan adverte sobre a causa do desejo e não objeto do desejo.

O que se deseja? Não é o sapatinho, nem o seio, nem seja o que for em que vocês encanem o fetiche. $O$ fetiche causa o desejo. $O$ desejo, por sua vez, agarra-se onde puder. Não é absolutamente necessário que seja naquela que calça o sapatinho; este pode estar em suas imediações. Sequer é necessário que seja ela a portadora do seio; o seio pode estar na cabeça. Mas todo o mundo sabe que, para o fetichista, 
é preciso que o fetiche esteja presente. $O$ fetiche é a condição mediante a qual se sustenta o desejo. (LACAN, [1962-1963] 2005, p. 116)

Entretanto será de grande valia demostrar como a produção do inconsciente literário na poesia de Manoel de Barros se revela através desta escrita que comtempla os detalhes rasteiros do ser, a ponto de observar como o desejo se apresenta e se faz valer através de cada alusão ao nada, ao vazio e por assim dizer a falta. Conceito este que em seu íntimo apresenta tarefa desafiadora. Dizer algo sobre o objeto a não é uma proposta simples, pois não se trata de um objeto como os demais, pertencente ao mundo do especular, mas, ao contrário, trata-se de um que é extraído dos demais. "Sobre o objeto a no ensino de Lacan, teria de dizer que, no Seminário X, Lacan o enuncia pela primeira vez e, a partir daí, este objeto vai passar por transformações e especificações" (WOLODARSKY, 2006).

Da mesma forma em que Freud ([1908] 2015) busca por intermédio de um caráter investigativo acerca da funcionalidade criativa do poeta, Lacan ([1962-1963] 2005) insiste em averiguar a qualidade e posição a qual pertence ao objeto a, como em qual lugar poderia se localizar, e supondo que essa proposta fosse cabível, e nos lembra de que reconhecer-se como objeto do próprio desejo é sempre uma posição masoquista. Mas ainda, de masoquista só se faz no palco, e mais, demostra o que acontece quando já não se pode mais sustentar essa atuação. "Quando não estamos em cena, quando ficamos aquém dela e procuramos ler no Outro qual é sua questão, só encontramos aí, em x, a falta" (LACAN, [1962-1963] 2005 p. 121).

De fato, o objeto liga-se a sua falta necessária ali onde o sujeito se constitui no lugar do Outro, isto é, o mais longe possível, no irredutível do incógnito não podemos dizer incognoscível, já que falamos dele, é aí que se estrutura e se situa o que, em nossa análise da transferência, produzi diante de vocês o termo ágalma. É na medida em que esse lugar vazio é visado como tal que se institui a dimensão sempre negligenciada, por razões evidentes, quando se trata da transferência. Esse lugar demilitado por algo que é materialização na imagem, uma borda, uma abertura, uma hiancia, onde a constituição da imagem especular mostra o seu limite, é o lugar da eleição da angústia. Esse fenômeno de borda, vocês encontraram por exemplo, em ocasiões privilegiadas, na janela que se abre, marcando o limite do mundo ilusório do reconhecimento, aquele que chamo de cena. (LACAN, [1962-1963] 2005, p. 121)

Jorge (2005) aponta que durante todo o percurso freudiano acerca da sexualidade, parte de uma premissa com qual Lacan buscou um retorno a Freud, de que, no núcleo da sexualidade humana estampa uma falta de objeto. Ao desenvolver o conceito de pulsão, Freud salienta que um dos quatro elementos que a compõem, é de que o objeto é indiferente, ou seja, dessa forma qualquer objeto pode ocupar o 
lugar de objeto da pulsão, e ainda Lacan deu um nome a essa falta de objeto a. E o tomando em uma dimensão única afirmando assim, ser essa a sua única invenção teórica. "O objeto a é apenas a presença de um cavo, de um vazio, ocupável, nos diz Freud, por não importar que objeto, e cuja instância só conhecemos na forma de objeto perdido". (JORGE, 2005, p. 139).

Desta forma Jorge (2014) esclarece que o objeto a é um objeto faltoso, ou ainda, perdido para qual o sujeito busca reencontrar, entretanto mesmo definindo como um objeto em in-existência é também definido como a causa do desejo, e na medida em que esteja ancorado a causa, mantem uma relação absolutamente presente com a falta.

Compreendendo esta possível definição do autor, e o intento deste exercício em acomodar a poesia e psicanálise na mesma direção, desta vez não em identificar $o$ ato criativo apenas, mas a comunhão deste movimento do poeta através do que discorremos sobre o objeto a, elenco abaixo o trecho do poema de Manoel de Barros, "Os deslimites da palavra" ([1993] 20015):

Ando muito completo de vazios.

Meu órgão de morrer me predomina.

Estou sem eternidades.

Não posso mais saber quando amanheço ontem.

Está rengo de mim o amanhecer.

Ouço o tamanho oblíquo de uma folha.

Atrás do acaso fervem os insetos.

Enfiei o que pude dentro de um grilo o meu destino.

Essas coisas me mudam para cisco.

A minha independência tem algemas.

(BARROS, [1993] 2015, p. 43)

Como é possível de observar no poema de Barros, a primeira frase aponta um jogo de palavras. Ao dizer ando muito completo de vazios, nota-se nessa manifestação poética o que Lacan propõe ao conceituar acerca da angústia como estatuto da falta, neste caso a angústia como ausência da falta. A predominância do órgão de morrer, órgão este não elegível, muito menos seletivo, seria uma alusão a um objeto que não existe e ainda obtém o domínio sobre o poeta. O que põe no sujeito limites, tirando assim as suas eternidades, reduzindo ao acaso? Qual seria o tamanho de um destino ao ponto em que caberia em um grilo? In-existencia! 
A angustia, ela não é sem objeto, e ainda que esse objeto não seja acessível pelo caminhos dos demais, não quer dizer que não exista, nem tampouco que se saiba ou que não saiba qual é, enfim, aqui encontramos a interpretação de que o objeto a não está no mundo do especularizavel, mas ainda sim pode ser deduzido (a sua falta). "A angustia nos introduz, com a ênfase da comunicabilidade máxima, numa função que, para o nosso campo é radical - a função da falta" (LACAN, 1962-1963/2005, p. 146).

Nesse percurso, o psicanalista demostra que a angústia é um fenômeno de borda que sinaliza o último limite anterior ao real e ao campo do gozo, mais precisamente a angústia acomete o sujeito quando algum acontecimento o remete ao mais íntimo de si mesmo, ocasionando um corte que se abre momentaneamente, nesse momento de vacilação do sujeito, a um registro desprovido de simbolização. (TEIXEIRA \& RESENDE, 2009).

De acordo com tal observação, o objeto a, está para o sujeito como aquilo que Ihe escapa ao lidar com a falta, sendo aquilo para que o sujeito busca, ou ao menos tenta dar um sentido ao que escapa do real, o objeto a esse nó borromeano.

O objeto a é estabelecido como aquilo que escapa por esse corte, como algo do real que se apresenta em decorrência de alguma situação que podemos considerar traumática. Sabemos que o trauma tem relação com a fratura, com o corte. E é desse corte que se desprende o objeto a. (TEIXEIRA \& RESENDE, 2009, p. 13)

Tendo em vista o que este conceito implica, o objeto a é algo de que o sujeito para se constituir, se separou como órgão (LACAN, [1962-1963] 2005, p. 101). A relação do sujeito com o que não the é idealizado, a relação do sujeito e os seus restos, traços e marcas. O sujeito, a falta e o desejo. "A causa do desejo é a, este objeto que está no exterior, anterior a qualquer interiorização, que pertence o objeto a, ideia de causa". (LACAN, [1962-1963] 2005, p.116).

Ensinam-nos, com efeito, que não há nenhuma noese, nenhum pensamento, que não esteja voltado para alguma coisa. Esse é o único ponto, ao que parece, que permite ao idealismo encontrar seu caminho para o real. Mas, pode o objeto do desejo ser concebido dessa maneira? Será que é no que diz respeito ao desejo? (...) Será que o objeto do desejo está a frente? Esta é a miragem de que se trata. Para fixar nossa meta, direi que o objeto a não deve ser situado em coisa alguma que esteja análoga a intencionalidade de uma noese. $\mathrm{Na}$ intencionalidade do desejo, que deve ser distinguida dele, esse objeto deve ser concebido como a causa do desejo. O objeto está atrás do desejo. (LACAN, [1962-1963] 2005, p. 114-115) 
Quinet (2002) propõe de maneira significativa uma possível compreensão do objeto a, observamos então. Em sua proposta ao apresentar o objeto a pela via escopica, ou seja, pelo olhar e não através dele (a visão), O objeto está naquilo que não vemos (ligado a falta), que não percebemos, está fora de uma compreensão empírica, e ainda assim não deixa de ser, aliás não deixa de existir, de nos fazer nele, como um número negativo, o fato de não estar confirma a sua existência, ou seja, a falta comprova a sua existência.

Ao elucidar a escrita do poeta Manoel de Barros (1993) em que ele diz ando muito completo de vazios, estou sem eternidades, não posso mais saber quando amanheço ontem, nota-se nesta expressão poética a função da escrita em não necessariamente buscar uma maneira de lidar com o que the falta, mas de se reconhecer através desta falta. "A poesia elege a falta não apenas como seu operador, mas como o seu tema, e diz invariavelmente de si mesma, mediante um retorno das línguas sobre si mesmas que sempre revela o vazio que tal percurso comporta". (SOUZA, 2014, p. 13).

Como é possível de observar na característica do poeta, essa dimensão na escrita de Barros embarca uma maneira de elucidar e identificar através do discurso onde se encontra o $\mathrm{EU}$, e nesse costume mental em encontrar o sujeito, a despeito do discurso que como lembra Lacan, sempre nos trai, onde imaginar nos situar como sujeito, situamos também "a", de maneira a contemplar a falta e a busca pelo objeto de seu desejo. "Ali onde existe no discurso o que vocês articulam como sendo vocês, em suma, ali onde vocês dizem EU (JE), é propriamente aí que, no nível inconsciente, situa-se a" (LACAN, 1962-1963/2005, p. 116).

Este objeto manterá uma duplicidade considerável, ao mesmo tempo em que será relacionado ao desejo, será apreendido também como objeto da angústia. O objeto a é o que lidamos no desejo e por outro lado na angústia (LACAN 19621963/2005, p. 179). Sendo assim as faces do objeto a seriam objeto causa-do-desejo e objeto causa-da-angústia E como afirma Lacan (1962-1963/2005), a angústia, não é sem objeto.

Poder-se-ia dizer então que a angustia está não apenas naquilo que por alguma razão ultrapassa o sujeito, mas também no que o atravessa e o põe através de algo, nesse objeto qualquer que seja e embora o esteja fora do sujeito vincula-se a ele de alguma forma, o instiga á algo ou aquém. E mesmo que vaguemos em prol do lúdico com a poesia manoelesca, é por ser esta uma via que possibilita a 
aproximação com o impossível, com o real, com o que está para o sujeito no seu mais íntimo e extimo.

\title{
CONSIDERAÇÕES FINAIS
}

De paradoxos em paradoxos, Manoel enaltece o nada, ilumina o homem em sua complexa simplicidade, e também adverte sem intenção ao preço que se paga pela mirabolancia de sermos sempre mais, pagamos pelo que somos cobrados, e ainda agradecemos para aquilo ou aquele que nos impõe ao que é ser feliz.

Bauman em "A arte da vida" implica quanto ao suposto valor que o sujeito acredita empregar à felicidade, e a inocência crença de que a certeza na vida é o caminho para dias melhores - penso eu que lidar com a felicidade e a certeza pode ser a maneira mais cruel de adoecimento frente a uma demanda social e capitalista . Pois vejamos bem, e que fique certo, "metade dos bens cruciais para a felicidade humana não tem preço de mercado nem pode ser adquirida em lojas" (BAUMAN, 2008 pag. 13).

\begin{abstract}
A incerteza é o habitat natural da vida humana, ainda que a esperança de escapar da incerteza seja o motor das atividades humanas. Escapar da incerteza é um ingrediente fundamental, mesmo que apenas tacitamente presumido, de todas e quaisquer imagens compósitas de felicidade. É por isso que a felicidade "genuína, adequada e total" sempre parece residir em algum lugar à frente; tal como o horizonte, que recua quando se tenta chegar mais perto dele. (BAUMAN, 2009, pag. 15)
\end{abstract}

Ao que posso complementar para que prossiga o desenlace deste artigo, diria no que se refere acerca de um possível diálogo entre a poesia de Manoel de Barros e a psicanálise de Freud e Lacan, que não apenas se fez presente neste exercício como também, se mostram dispostas a um diálogo com outros campos que caminhem na contramão de qualquer discurso ou conduta que idealize o homem, a vida e principalmente a felicidade. Tampouco que determine o que é ser saudável, ou que torne socialmente saudável o que quer que seja diante da vida. A poesia de Barros e porque não, até mesmo a própria poesia bem como a psicanálise está para além de qualquer estereotipo que se preste a saudar o sol em domingos depressivos e selfs no facebook com frases humanistas. Deixemos de ser governados por um discurso que capitaliza o homem dentro de uma cartilha de normas técnicas de indivíduos roboticamente saudáveis ou infelizes bem sucedidos, guiados por personal coachings tais como, rabulas, endomingados e engravatados, sejamos menos para sermos maiores do que qualquer culpa que possa surgir diante de tempos cruéis, em que o 
Poesia e Psicanálise: Um Possível Diálogo Entre Manoel de Barros, Freud e Lacan

homem se torna escravo da "felicidade". Creio que o amor esteja em pequenas coisas e em pequenas casas, voltemos à simplicidade e a coerência de nossos atos falhos. Voltemos, a saber, de que barro(s) somos feito e talvez não precisemos viver como se fossemos feito de ferro. 


\section{REFERÊNCIAS}

BARROCAS, Ricardo Lincoln Laranjeira; MARTINS, Osvaldo Costa. O fantasiar metapsicológico do psicanalista e aquele do escritor criativo: semelhanças e distinções. Psicologia em Revista, Belo Horizonte, v. 8, n. 3, p.50-53, dez. 2012. Disponível em: $<$ http://pepsic.bvsalud.org/scielo.php?script=sci_arttext\&pid=S1677-11682012000300008>. Acesso em: 24 set. 2016.

BARROS, Manoel de. O livro das ignorãças. Rio de Janeiro: Alfaguara / Objetiva, 1994. 120 p.

BARROS, Manoel de. Livro sobre nada. Campo Grande: Alfaguara / Objetiva, 1996. 100 p.

BARROS, Manoel de. O fazedor de amanhecer. Rio de Janeiro: Salamandra, 2001. 42 p.

BARROS, Manoel de. Poesia Completa. 2. ed. BRASIL: LEYA BRASIL, 2013. 480 p. v. 1.

BARROS, Manoel de. Meu quintal é maior do que o mundo. Rio de Janeiro: Alfaguara, 2015. $168 \mathrm{p}$.

BAUMAN, Zygmunt. A arte da vida. Rio de Janeiro: Zahar, 2009. 233 p.

CASTRO, Maria da Graça Kern; STÜRMER, Anie (Org.). Crianças e Adolescentes em Psicoterapia: A abordagem psicanalítica. Brasil: Artmed, 2009. 357 p.

DOMINGOS, João (Org.). Cautela e poesia em entrevista inédita de Manoel de Barros. O Estadão. Brasilia, p. 1-2. abr. 2001. Disponível em: $<$ http://cultura.estadao.com.br/noticias/literatura,cautela-e-poesia-em-entrevista-inedita-demanoel-de-barros, 1592199>. Acesso em: 04 set. 2016.

GONÇALVES, Wellington Bueno. MANOEL DE BARROS: o poeta das coisas sem importância. Uma poesia sobre nada. 2012. 21 f. Tese (Doutorado) - Curso de Literatura, Universidade Tecnológica Federal do Paraná - Utfpr, Curitiba, 2012. Disponível em: $<$ http://repositorio.roca.utfpr.edu.br/jspui/bitstream/1/1245/1/CT_LBHN_VII_2012_20.pdf $>$. Acesso em: 2 nov. 2016.

FREIRE, Giovana Guzzo (Org.). Psicanálise e Arte. Boletim do Ágora Instituto Lacaniano, Campo Grande, v. 2, n. 2, p.3-42, set. 2007.

FREUD, Sigmund. Um Caso de histeria. Três ensaios sobre a teoria da sexualidade e outros trabalhos. Rio de Janeiro: Imago, 1905. 400 p.

FREUD, Sigmund. "Gradiva" De Jensen e Outros Trabalhos 1906-1908 Vol. IX. Rio de Janeiro: Imago, 1908. 243 p.

FREUD, Sigmund. Escritores criativos e devaneios. Ed. Cidade. Editora, 1908.

FREUD, Sigmund. O mal-estar na civilização. Rio de Janeiro: Penguin e Companhia das Letras, 1929. $96 \mathrm{p}$.

GUEDES, Denise de Fátima Pinto. Uma introdução ao conceito de objeto a. Psicanálise \& Barroco em Revista, Juiz de Fora, v. 8, n. 1, p.159-174, jul. 2010. Disponível em: $<$ http://www.psicanaliseebarroco.pro.br/revista/revistas/15/p\&brev15guedes;.pdf $>$. Acesso em: 15 maio 2016.

JORGE, Marco Antonio Coutinho. Fundamentos da Psicanálise de Freud a Lacan: As bases conceituais. 2. ed. Rio de Janeiro: Zahar, 2005. 192 p.

LACAN, Jacques. O Seminário - Livro 10 - A Angústia. 1. Ed. [S.I.]: Zahar, 2005. 368 p. 
MANOEL de barros - Documentário 'Só dez por cento é mentira'.. Direção de Pedro Cezar. Campo Grande: Estante de Vídeo \& Áudio-livros, 2009. site, son., color. Disponível em: $<$ https://www.youtube.com/watch?v=QZLC8wNVtfs $>$. Acesso em: 02 set. 2016.

MANOEL DE BARROS (Org.). Fundação Manoel de Barros. Disponível em: $<$ http://www.fmb.org.br/>. Acesso em: 08 ago. 2016.

MORAIS, Marília Brandão Lemos. Poesia, psicanálise e ato criativo: uma travessia poética. Estudos de Psicanalise, Belo Horizonte, p.18-39, set. 2006. Disponível em: $<$ http://pepsic.bvsalud.org/scielo.php?script=sci_arttext\&pid=S0100-34372006000100008>. Acesso em: 30 out. 2016.

PUCHEU, Alberto. Manoel de Barros: em que acreditar senão no riso? Estudos Avançados, São Paulo, p.13-41, set. 2015.2 Disponível $<$ http://www.scielo.br/scielo.php?script=sci_arttext\&pid=S0103$40142015000300018 \&$ lang=pt $>$. Acesso em: 02 nov. 2016.

QUINET, Antonio. Um Olhar a mais: ver e ser visto na psicanálise. 2. ed. Rio de Janeiro: Zahar, 2004. 312 p.

RIBAS, Maria Cristina Cardoso. Só dez por cento é mentira, a desbiografia poética de Manoel de Barros: Poesia, vida \& documentário. 2011. Disponível em: $<$ http://docplayer.com.br/235128-So-dez-por-cento-e-mentira-a-desbiografia-poetica-demanoel-de-barros-poesia-vida-documentario-multiplos-eus-falando-de-si-documentarista-epoeta.html>. Acesso em: 22 ago. 2016.

RINALDI, Doris. Escrita e Invenção. [S.1.: s.n.], 2007. 52 p.

ROCHA, Jeferson Mello. Freud e o Dichter, ou "Por que a literatura?" 2015. 37 f. Tese (Doutorado) - Curso de Letras, Universidade Federal do Rio Grande do Sul, Porto Alegre, 2015. Disponível em: $<$ http://www.lume.ufrgs.br/bitstream/handle/10183/141701/000992177.pdf?sequence=1 $>$. Acesso em: 08 set. 2016.

SILVA, Célia Sebastiana. Manoel de barros: Sem margens com as palavras. 7. ed. Goiania: Fragmentos de Cultura, 2009. 550 p.

SOUZA JUNIOR, Paulo Sergio de. A poesia, o amor e o fracasso do inconsciente. Rio de Janeiro: Trivium, 2014. 15 p. $\quad$ Disponível em: $<$ http://pepsic.bvsalud.org/scielo.php?script=sci_arttext\&pid=S2176-48912014000200003>. Acesso em: 12 out. 2016.

STENNER, Andréia da Silva. A Identificação e a Constituição do Sujeito. 2. ed. Brasilia: Psicologia: Ciência e Profissão, 2004. 59 p. Disponível em: $<$ http://www.scielo.br/pdf/pcp/v24n2/v24n2a07.pdf>. Acesso em: 10 out. 2016.

VIOLA, Daniela Teixeira Dutra; VORCARO, Ângela Maria Resende. 2009. A formulação do objeto a a partir da teorização lacaniana acerca da angústia. Disponível em: $<$ http://pepsic.bvsalud.org/scielo.php?script=sci_arttext\&pid=S1518-61482009000300006>. Acesso em: 05 abr. 2016. 


\title{
SUBJECT, SPEECH AND IDEOLOGY: A PSYCHOANALYTICAL Poetry and Psychoanalysis: A Possible Dialogue between MANOEL DE BARROS, FREUD AND LACAN.
}

\begin{abstract}
The present article sought to present characteristics of the poetry of Manoel de Barros in a possible dialogue with the psychoanalysis of Freud and Lacan. The developments for this link came through the psychoanalytic perspective of the Freudian text of Creative Writers and Daydreams, and Lacan's concept of object, both articulated to cast a glance under the singularity in the poetry of Manoel de Barros, in poems that depict the subject in its simplicity, incompleteness, and more, proposes man as functional even in the place of not idealized.

KEYWORDS: Poetry. Psychoanalysis. Manoel de Barros. Freud. Lacan. Object a.
\end{abstract}




\section{Pó́sié et Psychanalyse: Um Dialogue Possible entre Manoel de BarRos, Freud et Lacan.}

\section{RÉSUMÉ}

Le présent article a cherché à présenter les caractéristiques de la poésie de Manoel de Barros dans un éventuel dialogue avec la psychanalyse de Freud et de Lacan. Les développements pour ce lien sont venus de la perspective psychanalytique du texte freudien des écrivains créatifs et des rêveries, et du concept d'objet de Lacan, tous deux articulés pour jeter un coup d'œil sous la singularité de la poésie de Manoel de Barros, dans des poèmes sujet dans sa simplicité, l'incomplétude, et plus, propose I'homme comme fonctionnel même au lieu de dés idéalisé.

MOT-CLÉS: Poésié. Psychanalyse. Manoel de Barros. Freud. Lacan. Objet a. 
Recebido em: 02-12-2018

Aprovado em: 25-04-2018

(C) 2018 Psicanálise \& Barroco em revista

http://www.seer.unirio.br/index.php/psicanalise-barroco/index

revista@psicanaliseebarroco.pro.br

Programa de Pós-Graduação em Memória Social — UNIRIO

Memória, Subjetividade e Criação

www.memoriasocial.pro.br/proposta-area.php 